\title{
HUKUM ADMINISTRASI NEGARA SEBAGAI HIMPUNAN PERATURAN-PERATURAN ISTIMEWA
}

\author{
Oleh: Chandra Aritonang \\ chandra.aritonang@uki.ac.id \\ Universitas Kristen Indonesia, Jakarta, Indonesia
}

\begin{abstract}
State Administration in every action must be based on law to solve and resolve the problem mentioned above or there is no law. The State Administration can be forced to use its authority to revoke regulations. Administration as a law maker in its application when related to legal systematics has caused controversial matters in essence State Administration is part of public law, so that all actions in the application based on its function are solely intended for and in the public interest, this is no different from the law State Administration, Criminal Law and Others. A situation can lead to deviations from the State administration of the systematics of law. Therefore the State Administrative Law as a set of special regulations.
\end{abstract}

Keywords: state administration; public law; special regulations.

\section{PENDAHULUAN}

Berawai dari permulaan abad XX, di Eropa sedang berkembang dengan pesat paham Negara Kesejahteraan (Welfare State). Dimulai dari pendapat yang dikemukakan oleh seorang Parlemen Inggris bemarna Beveridge, beliau mengemukakan gagasannya yang dikenal dengan istilah "Beveridge Report". Gagasan ini semulanya merupakan suatu program sosial dimana dia mengatakan bahwa Tujuan Negara Tidak Lain adalah Kesejahteraan Bagi Warganya.

Pada dasarnya gagasan Welfare State ini dikemukakan sebagai protes terhadap konsep Liberalisme yang sedang berkembang di dalam masyarakat, oleh karena paham liberalisme ini banyak membawa kemelaratan bagi masyarakat, khususnya di bidang perekonomian sekaligus menimbulkan persaingan yang tidak sehat diantara sesama warga.

Pada paham Welfare State ini, pandanngan yang merupakan tujuan bernegara adalah : Kesejahteraan Rakyat, dimana di dalam mewujudkan kesejahteraan tadi kepada pemerintah, khususnya pemerintah eksekutif (Administrasi Negara) diwajibkan untuk turut carnpur tangan didalam setiap aspek kehidupan masyarakat dan turut serta didalam pergaulan sosial masyarakat, dari uraian tersebut di atas apabila ditinjau dariaspek sejarah ketatanegaraan, dapatlah dipastikan bahwa lahirnya konsep Welfare State ini merupakan anti these dari sistem pemerintahan Monarki dan liberalisme,

Turut sertanya pemerintah Administrasi Negara didalam pergaulan sosial dalam paham Welfare State ini menimbulkan perluasan perundang-undangan sosial dan pertumbuhan Hukum Administrasi. Hal ini beralasan dari beberapa faktor penyebab antara lain :

1. Faktor Demografi yang begitu cepat populasinya,

2. Perkembangan Teknologi,

3. Insiden yang mempeiigaruhi perkembanga masyarakat.

4. Penyelenggaraan kesejahteraan rakyat berupa jaminan sosial. 
Dari faktor-faktor penyebab tadi menempatkan fungsi dan peranan Administrasi Negara menjadi sangat penting dan rnenentukan, mengingat bahwa didalam mewujudkan kesejahteraan sosial tadi Administrasi Negara sebagai salah satu institusi negara untuk mengembangkan tujuan negara (Welfare State merupakan ujung tombak perwujudan tersebut. Oleh beberapa pakar hukum seperti De Kat Angelino maupun Dr. Lemaire, menyebutkan fungsi dan peran administrasi Negara ini sebagai " Besturzorcf (fungsi pelayanan terhadap lasyarakat).

Sejalan dengan perkembangan negara hukum, khususnya konsep negara hukum "Rechtstaaf, sebagaimana yang dikemukakan oleh Julius Stahl, apabila ikaitkan dengan aktivitasaktivitas Administrasi Negara sebagai penyelenggara kepentingan umum maka Administrasi Negara didalam setiap tindakannya haruslah berdasarkan hukum (Asas Legalitas). Namun adakalanya didalam tindakan-tindakan Administrasi Negara untuk memecahkan dan menyelesaikan uatu permasalahan tadi tidak atau belum ada pranata perundang-undangannya. Dalam hal ini Administrasi Negara terpaksa menggunakan kewenangannya untuk mencabut peraturan (Freies Ermessen). Dari uraian tersebut di atas dapatlah dipahami bahwa, bertitik tolak dari kewenangankewenangan yang diberikan kepada Administrasi Negara telah menimbulkan pembentukan hukum baru, membentukan hukum tersebut bersumber dari tindakan Administrasi Negara.

Administrasi sebagai pembentuk hukum didalam penerapannya apabila dikaitkan dengan sistematika hukum telah menimbulkan hal-hal kontroversial pada hakekatnya Administrasi Negara merupakan bagian dari hukum publik, shingga segala tindakan didalam penerapan berdasarkan fungsinya semata-mata ditujukan untuk dan demi kepentingan umum, hal ini tidak berbeda dengan hukum Tata Negara, Hukum Pidana dan iain-lainnya. Berdasarkan logika hukum yang dianut dalam sistematika hukum, menunjukkan bahwa, Administrasi Negara sebagai bagian hukum publik tidak dapat bertindak berdasarkan hukum umum (hukum Private), namun dengan berpegang kepada Grand Teori Welfare State yaitu agar dapat mewujudkan kesejahteraan bagi rakyat maka pemerintah Administrasi Negara "harus turut campur tangan didalam setiap aspek kehidupan masyarakat dan ikut serta didalam pergaulan sosial masyarakat" sehingga Administrasi Negara dapat memperlakukan hukum umum (private) bilamana kepentingan diperlukan. disisi lain dapat pula kita lihat bahwa Hukum Administrasi Negara dapat menyampingkan (Contra Legem) peraturan perundang-undangan lainnya, selain itu dapat pula mengadoptir hukum lain didalam rangka kepentingannya. Uraian ini menggambarkan suatu keadaan terjadinya penyimpangan (deviasi) dari administrasi Negara terhadap sistematika hukum. Oleh karena itu Utrecht menyebutkan Hukum Administrasi Negara sebagai suatu himpunan peraturan istimewa.

Adapun permasalahan yang dikemukakan didalam penulisan makalah ini sebagai konsekuensi dari Faham Welfare State terhadap institusi Administrasi Negara yang telah menciptakan Hukum Administrasi Negara sebagai suatu himpunan peraturan-peraturan istimewa, namun dengan analisis yang bersifat deskriptif masih perlu dibuktikan antara lain :

1. Bagaimanakah hubungan antara Hukum Administeasi Negara dengan Hukum Perdata secara teoritis dan fungsionai.

2. Bagaimanakah peranan Hukum Administrasi Negara sebagai hukum istimewa dapat menjadi eiemen-elemen yang mutlak dalam proses penyelenggaraan kesejahteraan rakyat,

3. Dilihat dari luasnya kekuasaan Administrasi Negara menunjukkan kecenderungan terjadinya penyalahgunaan hak dan wewenang, oleh karena itu upaya-upaya apa sajakah yang digunakan untuk membatasi serta mengawasi tindakan-tindakan dari Administrasi Negara? 


\section{PEMBAHASAN}

\section{Pengertian}

Secara sederhana dapat dirumuskan pengertian "Administrasi" adalah Tata Usaha, sedangkan "Negara" ialah persekutuan bangsa dalam suatu daerah yang tentu batas-batasnya yang diperintah dan diurus oleh badan pemerintahan yang teratur.

Sedangkan yang dimaksud dengan "Istimewa"' ialah yang lain dari yang lain, Dalam makalah ini memberi arti bahwa hukum Administrasi Negara sebagai himpunan peraturan istimewa memiliki spsifikasi tersendiri dan berbeda, apabila dibandingkan dengan hukum lainnya seperti Hukum Perdata, Hukum Pidana dan hukum lainnya.

Pada dasarnya Administrasi Negara adalah satu bagian daripada Administrasi umumnya merupakan salah satu cabang ilmu sosial dimana Administrasi Negara mempunyai kaitan erat sekali dengan kelompok ilmu-ilmu sosial lainnya, antara lain dengan Ilmu Hukum, Ilmu Politik dan lain-lain, Herbert A, Simon berpendapat bahwa Administrasi Negara adalah kegiatan-kegiatan daripada bagian badan eksekutif pemerintahan nasional. negara bagian, pemerintahan daerah; dewan-dewan dan panitia-panitia yang dibentuk oleh Congress; badan-badan kenegaraan lain yang mempunyai ciri khusus. Secara khusus dikecualikan adalah badan-badan yudikatif dan legislatif didalam administrasi pemerintall. Oleh karena itu Administrasi Negara sebagai bagian dari ilmu sosial yang mempeiajari kegiatan-kegiatan badan eksekutif pemerintahan nasional.

Terhadap Administrasi Negara yang menganut Faham Welfare State selain memperoleh legitirnasi untuk merijalankan pemerintalian dan penyelenggara kesejahteraan rakyat, didalam kegiatannya diwujudkan berupa :

1. Penetapaii (Beschikking).

2. Rencana (Plan)

3. Norma Jabaran (Concreto Normgeving)

4. Legislasi Semu (Pseudo Van Wetgeving)
Kesemuanya ini merupakan keputusan Administrasi Negara, namun didalam pembentukan Hukum Administrasi Negara, penetapan (beschikking) adalah produk-produk Administrasi Negara yang menimbulkan hubungan secara langsung dengan masyarakat.

Dengan demikian segala tindakan-tindakan Administrasi Negara didalam menjalankan peraturan perundang-undangan dan fungsi pelayanan (Bestuurzorg) adalah untuk menciptakan hukum, yang disebut sebagai Hukum Administrasi Negara, Selanjutnya oleh "Prof. Mr. Dr. Prayudi Atrriosudirdjo" memberikan definisi dari Hukum Administrasi Negara sebagai "Hukum mengenai Administrasi Negara dan Hukum hasil ciptaan Administrasi Negara".

\section{Tujuan Hukum}

Tujuan hukum ialah "mengatur pergaulan hidup secara damai”. Hukum mengadakan perdamaian", pikiran ini diucapkan dalam salah satu prolog dari rakyat "Franka Salis", Lex Salica (500 tahun SM). Oleh u keadaan hukum bertujuan untuk kedamaian hidup antar pribadi. Kedamaian itu meliputi dua hal yaitu : Ketertiban ektern antar pribadi ketenangan intern pribadi. Kedua hal tersebut ada hubungannya dengan tugas kaedahkaedah hukum yang bersifat dwi tunggal yang merupakan sepasang nilai dimana tidak jarang bersitegang yaitu :

1. Memberikan kepastian dalam hukum (Zekerheid).

2. Memberikan kesebandingan dengan hukum (Billijkheid).

3. Manfaat (Utilitie).

\section{Teori Hukum Modern}

Beralasan dari sifat-sifat dasar teori $\mathrm{Hu}-$ kum Konvensionalisme dimana netral, otonom, futuristik dan non poiitis dalarn penerapannya justru menimbulkan individualisme kuantitatif (dasar egoisme) dalam masyarakat telah membentuk corak kapitalisme, kecenderungan 
hukum yang selalu berpihak pemilik ekonomi yang kuat, sementara diikat dengan doktrin pemerintah oleh campur tangan dalam kehidupan masyarakat (Nacht Woeker Staat) menimbulkan ketidak puasan kaum masyarakat ekonomi lemah (Wong Cilik) dan sekaligus menempatkan dalam suatu lingkungan masyarakat sempalan (The Outsider).

Sebagai reaksi terhadap konsep teori konvensionalisme ini timbul suatu paradigma baru didalam upaya penyelenggaraan tujuan hukum dalarn kehidupan masyarakat yaitu Teori Hukum Modern.

Pada teori hukum modern ini menekankan pada masalah sebagai berikut :

1. Hukum harus bersifat politik

2. Hukum adalah salah satu ajaran semi otonom

3. Hukum harus bertumpu pada sejarah

4. Hukum tidak dari sekedar mempelajari keputusan hakim

5. Hukum lebih dari sekedar mempelajari keputusan hakim

6. Cakupan teknik hokum lebih dari metode hokum public dan tidak seharusnya terkait pada kategori hokum public/umum klasik ${ }^{11)}$ Dari konsep teori umum modern ini secara implisit menggambarkan tujuan hokum kesejahteraan rakyat. Pemerintah Welfare State yang bertujuan untuk hukum untuk kesejahteraan rakyat yang diimplementasikan melalui aktivitas Administrasi Negara merupakan perwujudan dari teori hukum modern, hal tersebut dapat kita lihat tumbuh dan berkembangnya Administrasi Negara adalah sebagai tuntutan dari Konsep Welfare State itu sendiri, sementara konsep ini lahir/timbul berlatar belakang dari sejarah Liberalisme, selanjutnya didalam pembentukan hukum itu sendiri tidak lagi menjadi otonom oleh karena didalam mewujudkan tujuan-tujuan negara memerlukan kebijakan-kebijakan politik yang menempatkan hukum menjadi semi otonom, paradigm baru ini menempatkan posisi Lembaga Legislatif dan Yudikatif.

\section{Pembahasan}

Secara abstrak pengertian negara suatu badan hukum (Persona Moralis), dimana tuuan tertentu menurut konsep Welfare State tujuan negara tidak lain adalah kesejahteraan bagi rakyat. Didalam mewujudkan kesejahteran tersebut diperlukan suatu kebijakan (policy), selanjutnya kebijakan tersebut lebih menekankan pada Administrasi Negara untuk campur tangan didalam setiap aspek kehidupan masryarakat dan ikut serta didalam pergaulan sosial masyarakat. Dimungkinkannya Admirustrasi Negara untuk bertindak seperti itu beralasan dari sistem pemerintahan dalam konstelasi supra struktur yang menganut Faharn Welfare Slate dimana kedudukan Administrasi Negara mempunyai arti sebagai berlkut:

1. Aparatur Negara, aparatur pemerintah atau sebagai institusi politik kenega- raan.

2. Fungsi atau sebagai aktivitas meiavani pemerintah yakni sebagai kegiatan pemerintah operasional.

3. Proses teknis penyelenggaraan

Selanjutnya didalam memahami kedudukan Administrasi Negara dalam konstelasi politik negara, Prof. Mr. AM. Dorner memberikan pengertian pemerintah dalam dua bentuk kekuasaan yaitu :

1. Alat-alat pemerintahan yangmenentukan haluan politik Negara (Taakstelling).

Kalau diimplementasikan pengertian ini di Indonesia adalah lembaga Tertinggi Negara Yaitu MPR RI.

2. Alat-alat pemerintahan yang menyelenggarakan/mereaiisasikan politik negara yang telah ditentukan. Di Indonesia ada lima lembaga tinggi negara, salah satunya ialah Lembaga Tinggi Kepresidenan, oleh karena UUD 1945 harapir 1 /3 mengatur tentang kekuasaan Presiden, maka Presiden berdasarkan pasal 4 UUD 1945 sebagai kepala pemerintahan, diartikan sebagai kepala Administrator. 


\section{Hubungan antara Hukum Administrasi Neg- ara dengan Hukum Perdata}

Didalam memahami korelasi suatu disiplin hukum dengan disiplin hukum lainnya, tidak terlepas dari doktrin yang diutarakan oleh para pakar hukum, begitu juga hubungan antara $\mathrm{Hu}-$ kum Administrasi Negara dengan Hukum Perdata. Didalam memahami hubungan kedua hukum tersebut dapat kita lihat pendapat dari Mr. Paul Scholten ${ }^{14}$, beliau mengatakan bahwa "Hukum yang dapat dibedakan dari hukum perdata sebagai hukum yang bersifat sendiri adalah hanya hukum tentang organisasi masyarakat, sebutkan hukum konstitusional. Akan tetapi sepanjang hukum publik tidak mengadakan aturan-aturan yang lain, maka dimanapun hukum perdata itu berlaku sebagai hukum umum atau umum rakyat".

Apabila kita simak pendapat Paul Scholten tersebut di atas bahwa Hukum Administrasi Negara itu merupakan hukum khusus tentang organisasi negara dan hukum perdata sebagai hukum umum. Pendapat ini mengandung dua asas yaitu sebagai berikut:

1. Bahwa Negara dan badan hukum publik lainnya dapat menggunakan peraturan dari Hukum Perdata, sebagaimana diatur pada hukum perjanjian yang terdapat dalam Buku III KUHP Perdata.

2. Berdasar dari Adagium Lex spesialis derogate Lex Generalist yaitu bahwa hukum khusus menyampingkan hukum umum, yang memberi arti; Apabila suatu peristiwa hukum diatur baik oleh Hukum Administrasi Negara, maupun oleh Hukum Perdata, maka peristiwa ini diselesaikan berdasarkan $\mathrm{Hu}$ kum Negara sebagai hukum khusus, jadi tidak diselesaikan Hukum Perdata sebagai hukum umum. Namun didalam mengenyampingkan" hukum umum ini harus memperhatikan sah serta berlakunya suatu Undang Undang. Bahwa dimungkinkannya hukim khusus mengenyampingkan hukum umum (Contra Legem] apabila : a. BerdasarkanHirarkiperundang-undangan kedudukan hukum khusus harus sama ( $\mathrm{Ne}$ ben) dengan kedudukan hukum umum.

b. Bahwa pada hukum khusus didalam salah satu pasalnya, harus secara jelas menyebutkan pengenyampingan hukum lain, sebagai contoh dapat kita lihat pasal 7 UU No. 19 Tahun 1997, tentang Penagihan Pajak Dengan Surat Paksa, dimana disebutkan terhaclap wajib pajak yang tidak melaksanakan kewajibannya ciapat dilaksanakan sita eksekusi atas harta miliknya tanpa persetujuan pengadilan. Dalam hal ini telah terjadi Contra Legem terhadap Reglernent Op de Rechterlijke Grganisasie Van Justice (R.O) Jo. UU No. 14 Tahun 1970, maupun yang diatur pada RV dan HIR.

Administrasi Negara didalam fungsihnya menjalankan UU Maka Administrasi Negara dapat menggunakan alat paksa, agar masyarakat/ individu tersebut tunduk pada kekuasaannya berdasarkan wewenang tadi, Hal ini dapat Idta lihat pada sal t UU R1 No. 19 Tahun 1997, tentang Penagihan Pajak Dengan Surat Paksa aana disebutkan : "Surat Paksa berkepala kata-kata "DEM1 KEAD1LAN RDASARKAN KETUHANAN YANG MAHAESA* mempunyai kekuatan jekutorial dan kedudukan hukum yang sama dengan putusan pengadilan yang ah mempunyai kekuatan hukum tetap.

\section{KESIMPULAN}

Dari sisi pasal 7 UU RI No. 19 Tahun 1997 tersebut, dapat dipahami bahwa hadap wajib pajak yang tidak melaksanakan kewajibannya setelah melalui proses somasi, maka terhadap wajib pajak tersebut dapat dilaksanakan sita sekusi atas harta miliknya tanpa persetujuan pengadilan. Dari uraian tersebut pat kita simpulkan bahwa dengan dikeluarkannya pasal 7 UU No. 19 Tahun 1997 tersebut Hukum Administrasi Negar telah menyampingkan (Extra Legem) peraturan-peraturan didalam Hukum Acara Perdata. Bahwa dengan 
dikeluarkannya UU tersebut, sebagian kewenan- gan yudikatif telah diambil Hukum Administrai Negara.

Dengan uraian-uraian yang sederhana ini dapatlah dipahami bahwa rtitik tolak dari konsep Welfare State, telah menempatkan kedudukan Hukum ministrasi ffegara sebagai hirnpunan peraturan-peraturan yang istimewa, caligus se- bagai elemen-elemen yang mutlak dalam proses penyelenggaraan sejahteraan rakyat.

\section{Daftar Pustaka}

1. Djenal Hoesen Kusumahatmadja, Pokok- Pokok Hukum Tata Usaha Negara, Citra Aditya Bhakti, Bandung, 1990.

2. E. Utrecht, Hukum Administrasi Negara, Sinar Harapan, Jakarta, 1990.

3. Indroharto, Usaha Memahami Undang Un-dang tentang Peradilan Tata Usaha Negara, Sinar Harapan, Jakarta, 1991.

4. Muchsan, Peradilan Administrasi Negara, Liberty, Yogyakarta, 1981.

5. Prayudi Atmosudirdjo, Hukum

Administrasi Negara, Ghalia, Jakarta, 1981.

6. Soewarno Handayaningrat, Administrasi Pemerinlahan Dalam Pembangunan Na-sional.

7. W.F. Prins-R. Kosim Adisaputra, Pengantar Hmu Hukum Administrasi Negara, Pradnya Paramita, Jakarta, 1976. Lima Undang Undang Perpajakan 1997. Himpunan Makalah Asas-Asas Umum Pe- merintahan Yang Baik, Lembaga Penelitian dan Pengembangan Hukum Administrasi Negara, Bogor Jakarta, Citra Aditya Bhakti, Bandung, 1994. 